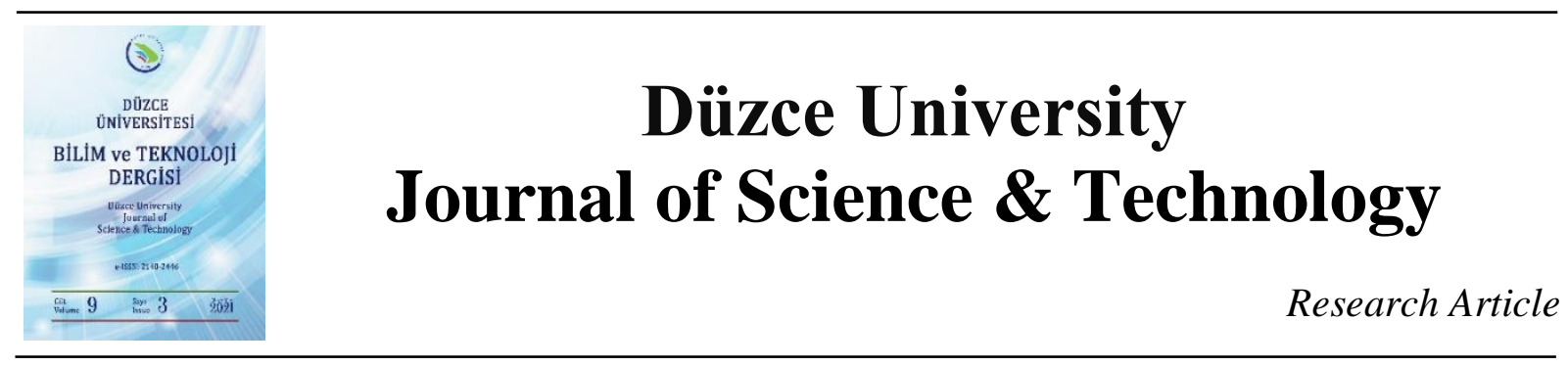

\title{
Risk Analysis Application in Highway Projects
}

\author{
Ali Erkan KARAMAN ${ }^{\text {a,* }}$, (D) Eray KÖSEOĞLU ${ }^{\text {b }}$ \\ ${ }^{a}$ Department of Civil Engineering, Faculty of Engineering, Ballkesir University, Ballkesir, TURKEY \\ ${ }^{b}$ Department of Civil Engineering, Institute of Science, Balıkesir University, Balıkesir, TURKEY \\ * Corresponding author's e-mail address: ekaraman@balikesir.edu.tr
}

DOI: $10.29130 /$ dubited.848112

\begin{abstract}
Highway projects are large investment projects and have many risk factors. It is possible to reduce the problems that may affect the success of a project by managing such risk factors through a comprehensive risk management strategy. In this study, it was aimed to determine the significance levels of risk factors faced in highway projects. Risk factors seen in agreement, design and construction stages of highway projects were specified by carrying out a literature review. The specified risk factors were classified under 7 main titles according to the source of risk, and emergence of the relevant risk factor at which stage of the highway project along with which sub-risks was investigated. Risk factors were evaluated by administrating questionnaires to the individuals experienced in highway projects and specialised in their fields. Later on, risk analysis was performed using the decision matrix method and their importance levels were determined. Obtained results suggested that the risk of economic crisis under the title of economic and political risks was the most important risk factor.
\end{abstract}

Keywords: Highway projects, risk analysis in highway projects, decision matrix method.

\section{Otoyol Projelerinde Risk Analizi Uygulamas1}

\begin{abstract}
ÖZET
Otoyol projeleri büyük yatırım projeleri olup birçok risk faktörünü içerisinde barındırmaktadır. $\mathrm{Bu}$ risk faktörlerinin kapsamlı bir risk yönetimi stratejisi ile yönetilmesiyle proje başarısını etkileyebilecek olumsuzlukların azaltılması mümkündür. $\mathrm{Bu}$ çalışmada otoyol projelerinde karşılaşılan risk faktörlerinin önem derecelerinin belirlenmesi amaçlanmıştır. Otoyol projelerinin sözleşme, tasarım ve yapımında karşılaşılan risk faktörleri literatür taraması yapılarak belirlenmiştir. Belirlenen risk faktörleri riskin kaynağına göre 7 ana başlıkta sınıflandırılarak ilgili risk faktörünün otoyol projesinin hangi aşamasında hangi alt risklerle ortaya çıktı̆̆ 1 araştrılmıştır. Risk faktörleri otoyol projelerinde tecrübe sahibi ve konusunda uzman kişilerce anket yöntemi ile değerlendirilip, karar matrisi yöntemi kullanılarak risk analizi yapılıp önem dereceleri belirlenmiştir. Elde edilen sonuçlar ekonomik ve politik riskler başlı̆ı altındaki ekonomik kriz riskinin en önemli risk faktörü olduğunu ortaya koymuştur.
\end{abstract}

Anahtar Kelimeler: Otoyol projeleri, otoyol projelerinde risk analizi, karar matrisi yöntemi. 


\section{INTRODUCTION}

The world is getting smaller day by day and the borders for companies are removed. Competition environment and increasing value of time raise the importance of highway projects. Highway projects play a great role in the development of transportation network and economic growth of a country. The adequacy and size of a transportation network are considered to be indicators of a country's economic development. The $9 \mathrm{~km}$ road named AVUS, located in the south of Berlin, is the first highway in the world and was built in 1921. The first highway in Turkey is the $23 \mathrm{~km}$ road, covering the Bosporus Bridge, which was put into service in 1973 [1].

There are many dangers and various risks caused by these dangers in construction projects. Risk is defined to be the likelihood of a circumstance and combination of effects of this case on project objectives. While a positive result leads to an opportunity, a negative one results in a danger [2]. Risk management is a project management technique including the processes of describing the risks regarding a project, determining the impacts of these risks on a project and deciding on the measures to be taken in the event of emergence of risks. Highway projects have different rates of risks, depending on the size, complexity and environment of a project. Management of these risks by a comprehensive risk management process will enable to reduce the problems that may affect the project success. The most important stage of the risk management system is to specify all risk factors that will influence a project. Therefore, an identified risk no longer becomes a risk but turns into a management problem. A misdeveloped risk identification study can lead to the collapse of all risk managements [3].

Highway construction activities involve a large number of dangers and risks. These risks are caused by several people, such as design department team, construction contractors, subcontractors, workers, and pose a major threat to construction speed and performance standards. Various risks emerge during projecting, construction and operation stages of highways. If these risks take place, important consequences, such as loss of time, route change, cost increase and financial difficulty may be observed. Therefore, in order to keep project cost under control, to protect quality and to ensure project progress in accordance with work programme, it is necessary to develop a risk assessment covering identification of all risks, classification of risks, evaluation by risk analysis [4].

The studies in the literature show that risk management is of paramount importance for construction projects in general respect and specifically for highway projects. In this study, it was aimed to grade the risk factors observed in the highway projects in Turkey. Thus, privileged risk factors will be determined rapidly at the beginning of the highway projects to be carried out.

\section{RISK ASSESSMENT IN HIGHWAY PROJECTS}

PMBOK [5] defines a project risk to be uncertain events and circumstances that may affect the project objectives negatively if such a risk occurs. Each risk has causes and results. Mustafa and Al-Bahar [6] argue that construction projects have many risks due to their complex structures, such as subcontractor failures, negative weather and site conditions, which are observed from beginning to end of projects.

Tah et al. [7] has examined and classified the risk factors seen in the construction sector under two groups as internal risks and external risks. While the internal risks refer to labour force, facility, material, subcontractor, site, contractual and location, the external risks relate to inflation, exchange difference changes and changes in employer requests. Özbey [8] has discussed the risks observed in transportation projects under 6 main headings. These are ranked to be design risks, construction site risks, construction risks, financial risks, permission and approval risks and contractual risks. Vishwakarma and Salunkhe [9] have analysed the risks on highway projects by a questionnaire study, and specified time, design, ground condition and expropriation to be the most important risk factors. The risk factors seen during 
the agreement, design and construction stages of highway projects have been classified according to their sources in Table 1 under 7 main headings as a result of the literature review carried out.

Table 1. The factors causing delay in the literature.

\begin{tabular}{ll}
\hline $\begin{array}{l}\text { Problems Affecting Time in Highway } \\
\text { Projects }\end{array}$ & Literature \\
\hline Risks caused by design & Zou et al. [10], Vishwakarma and Salunkhe [9] \\
Economic and market risks & Tam et al. [11], Mahamid et al. [12] \\
Political and social risks & Birgönül and Dikmen [3] \\
Construction risks & Özbey [8], Thapanont et al. [13] \\
Site risks & Edwards [14] \\
Contractual risks & Perera et al. [15], Edward [14]. \\
Occupational safety and environmental risks & Reilly and Arrigoni [16], Aydos [17] \\
\hline
\end{tabular}

Considered to be the most important stage, the design is the initial stage of all projects. It is clear that missing, faulty and unplanned designs will lead to many risks in the construction of a highway project. Highway projects are implemented in large areas, and these areas have different ground conditions. The risk factors to be caused by missing knowledge of designers related to the topography of a region result in design problems [9]. What is more, the general risks regarding the design are failure to complete and deliver projects and specifications on time, late material decisions, misunderstanding of employers' requests and inability to make proper designs due to insufficient information about the project area and employing inexperienced teams [10]. The problems that cannot be solved at the design stage affect the site work program negatively by continuing during the construction stage [18].

Economy and market risks are always effective in the construction stage. The highway projects built by the Public-Private Cooperation (PPC) model is financed by the company undertaking the construction. Companies generally obtain required finance by loans received from banks as they do not prefer to provide any finance by their own funds or inability to have sufficient resource while providing finance for highway projec [11]). As the required finance amount is high, the process of obtaining a loan may take a long time. Any problem to be faced in obtaining a loan may prevent all other stages of a project. Therefore, the risks that may be observed during obtaining a loan for a highway project should be analysed well and taken into consideration during submitting a tender offer. Another economy-related risk factor for developing countries is inflation. High inflation in a country decreases confidence in national currency. Any rise in inflation poses a serious risk by negatively affecting the highway projects in which significant purchasing transactions are performed [12].

Political and social risks may always influence the project success to a great extent. The problems such as embargo and risk of war that may affect economic system of a country may cause crises in national economy. Political and economic crises likely to occur may result in stopping a highway project. Considering that highway projects are generally long-term projects, the political structure of the country where the project takes place should be analysed well and measures should be taken for political risks that may be seen [3].

Construction risks are caused by unplanned work programmes as well as missing and faulty applications on the site. Many problems may be witnessed in the event of an unplanned work programme. In highway project tenders, companies provide construction and operation time offers by the Public-Private Cooperation (PPC) model. In the event that construction time is exceeded due to an error in work planning, planned operation time is shortened. This may result in serious money loss for companies [8].

The site risks include the following factors: failure to coordinate labour force effectively, inability to establish site mobilization completely or timely, landslides on slopes in a project, insufficient drilling information about the existing land structure. This is one of the most difficult stages in the risk assessment because this stage covers many unknown factors in addition to possible risks [14]. 
Agreements specify the rules to be followed by companies and provide risk distribution. The price of a work to be done, even partially, reflects the risk predicted by the person who will do this work. Employers are held responsible for any inadequacy in an agreement and amendments to be made in an agreement [14]. Uncertainties in agreements about responsibilities often reflect negatively on project success as cost increase.

There is a risk of many occupational accidents in highway projects due to various reasons. While some of these occupational accidents result in financial damage, there are unfortunately losses of lives. Loss of lives and properties that may occur due to occupational accidents result in labour loss by affecting the motivation of employees negatively. In addition, an occupational accident may cause an interruption of a company's works for a certain or uncertain period. Accordingly, this causes delays in related workshops [17].

\section{RESEARCH METHOD}

The data required for this study, aiming to develop a risk assessment in highway projects and to rank the importance of the identified risks, was collected by administrating a questionnaire. The questionnaire form used in this study was prepared in accordance with the principles specified by scientific research methods [19]. Subjects were asked to make an "impact" and "probability" evaluation for the risks in this questionnaire form. The scale regarding the impact and degree of probability is provided in Table 2.

Table 2. Probability - impact scales in the Decision Matrix.

\begin{tabular}{|c|c|c|c|}
\hline Score & \multicolumn{2}{|c|}{ Probability / Impact } & Grading steps for probability of realisation \\
\hline 1 & \multirow{5}{*}{ 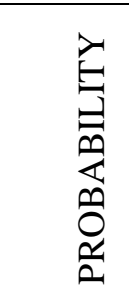 } & Very Small & Any risk is not expected, very unlikely to occur. \\
\hline 2 & & Small & Very small risk probability. May be repeated once a year. \\
\hline 3 & & Intermediate & There is a risk albeit little. May be repeated once a year. \\
\hline 4 & & High & There is a risk. May be repeated once a month, week. \\
\hline 5 & & Very High & A risk may occur anytime. \\
\hline 1 & \multirow{5}{*}{ 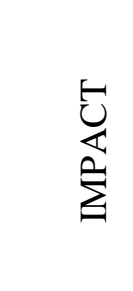 } & Very Little & Scarcely any impact, negligible \\
\hline 2 & & Little & Recoverable \\
\hline 3 & & Intermediate & A significant impact \\
\hline 4 & & Serious & $\begin{array}{l}\text { An impact that may have significant consequences for a } \\
\text { project }\end{array}$ \\
\hline 5 & & Very Serious & Unavoidable financial loss or delay in a project \\
\hline
\end{tabular}

The sample and target responders of this study, in which a risk assessment would be carried out in highway projects, consisted of technical staff (engineers and architects) working on highway projects. In order to increase the value added by target responders to the research, it was taken into consideration to collect data from the technical staff with more experience in highway projects. After determining the sample and target responders, it was come into contact with 50 technical staff by face-to-face interviews.

The questionnaire form named after "Risk Assessment in Highway Projects" consisted of 7 main sections and includes 69 risk factors (Table 3). The risk factors provided in Table 3 were evaluated by the target responders according to the measurement scale given in Table 2. The "decision matrix method", one of the risk rating methods, was used for data analysis. By this method, it was attempted to determine the size of each risk factor by measuring probability and impact values of the risks. The size of a risk is obtained by multiplying the probability and impact values. While assessing the data obtained 
from 50 subjects, the median method was preferred instead of using the average method. Because it is more realistic by this method to reveal the prevailing opinions of the subjects about the risks [20].

Table 3. Main and sub-risk factors regarding highway projects.

\begin{tabular}{|c|c|c|}
\hline $\begin{array}{l}\text { Risk } \\
\text { Code }\end{array}$ & Risk Category & Risk Factor \\
\hline RCD1 & \multirow{8}{*}{$\begin{array}{l}\text { Design } \\
\text { related } \\
\text { risks }\end{array}$} & Complexity and applicability of design \\
\hline RCD2 & & Design defects \\
\hline RCD3 & & Obtaining insufficient and/or wrong information about project area \\
\hline RCD4 & & Uncertainties and defects in project details \\
\hline RCD5 & & Inadequate and inexperienced design team \\
\hline RCD6 & & Lack of Communication and Coordination \\
\hline RCD7 & & Uncertain ground conditions \\
\hline $\mathrm{RCD} 8$ & & Failure to deliver project on time \\
\hline EMR1 & \multirow{11}{*}{$\begin{array}{l}\text { Economy and } \\
\text { market risks }\end{array}$} & Economic crises \\
\hline EMR2 & & Inflation \\
\hline EMR3 & & Currency fluctuations \\
\hline EMR4 & & Obtaining loan \\
\hline EMR5 & & Delays in Payments (Progress Payment Delays etc.) \\
\hline EMR6 & & Errors to be made in cost estimation \\
\hline EMR7 & & Cost due to failure to complete work on time \\
\hline EMR8 & & Subcontractor's exceeding specified time and cost limits \\
\hline EMR9 & & Sudden changes in raw material, material and equipment prices \\
\hline EMR10 & & Bankruptcy of the main company-subcontractor \\
\hline EMR11 & & Dependency on external funds \\
\hline PSR1 & \multirow{8}{*}{$\begin{array}{l}\text { Political } \\
\text { social risks }\end{array}$} & Amendments in laws, legislation and regulations \\
\hline PSR2 & & Regulations and difficulties required for permissions \\
\hline PSR3 & & Bureaucratic procedure (speed, delays in implementation, etc.) \\
\hline PSR4 & & Protests of civil society organizations/public against project \\
\hline PSR5 & & Embargo and war \\
\hline PSR6 & & Expropriation problems \\
\hline PSR7 & & Social unrest (events such as riot and strike etc.) \\
\hline PSR8 & & Burglary (machine material theft etc.) \\
\hline CR1 & \multirow{18}{*}{$\begin{array}{l}\text { Construction } \\
\text { risks }\end{array}$} & Applicability work programme \\
\hline CR2 & & Using improper construction technique \\
\hline CR3 & & Acceleration demand of project by employer or government \\
\hline CR4 & & Undesired quality of work and need to do it again \\
\hline CR5 & & Lack of communication and coordination in project team \\
\hline CR6 & & Change in project route \\
\hline CR7 & & Change in construction priorities \\
\hline CR8 & & Conflict between project and existing transport network \\
\hline CR9 & & Problems in raw material/material procurement \\
\hline CR10 & & Problems in machinery/equipment supply \\
\hline CR11 & & Capacity and experience of technical staff \\
\hline CR12 & & Technical staff change \\
\hline CR13 & & Subcontractor selection \\
\hline CR14 & & Difficulty of finding a warehouse site and borrow pit \\
\hline CR15 & & $\begin{array}{l}\text { Labour force (tiredness, distrust, inefficiency, poor workmanship, } \\
\text { etc.) }\end{array}$ \\
\hline CR16 & & Conflict and lack of communication between partners \\
\hline CR17 & & Management and organizational errors \\
\hline CR18 & & Transportation and shipping problems \\
\hline
\end{tabular}


Table 3(continue). Main and sub-risk factors regarding highway projects.

\begin{tabular}{|c|c|c|}
\hline SR1 & & Late establishment of site mobilization (concrete plant etc.) \\
\hline SR2 & & Failure to manage labour force effectively on site \\
\hline SR3 & & Unforeseen site and ground conditions \\
\hline SR4 & & Rough land conditions \\
\hline SR5 & & Delay in workplace delivery \\
\hline SR6 & Site ricls & Need for infrastructure displacement on site \\
\hline SR7 & STE IISKS & Groundwater level \\
\hline SR8 & & Slope flows \\
\hline SR9 & & Transportation to site \\
\hline SR10 & & Natural disasters likely to occur during implementation of project \\
\hline SR11 & & Bad weather conditions \\
\hline SR12 & & Founding archaeological remains on site \\
\hline COR1 & & Agreement size \\
\hline COR2 & & Duration of agreement \\
\hline COR3 & contractual & Responsibilities in agreement \\
\hline COR4 & & Conditions of agreement and risks related to penal sanctions \\
\hline COR5 & & Unbalanced risk distribution in agreement \\
\hline OSER1 & & Falling down from height \\
\hline OSER2 & & Material fall \\
\hline OSER3 & Occupational & Problems likely to be seen in blasting activities \\
\hline OSER4 & sarety and & Rollover of vehicles \\
\hline OSER5 & environmental & Loss of reputation due to occupational accident \\
\hline OSER6 & & Penal sanction due to work accident \\
\hline OSER7 & & Complaints likely to occur due to soil, water, air and noise pollution \\
\hline
\end{tabular}

\section{RESEARCH FINDINGS}

The reliability analysis of data was performed before carrying out the risk assessment by the data obtained from 50 experienced subjects working in highway projects and expert in their fields. The reliability analysis is performed to determine the self-consistency of the questions within the measurement topics. The Cronbach alpha $(\alpha)$ values obtained as a result of the reliability analysis and the mean and standard deviation values regarding the variables are provided in Table 4.

Tablo 4. The mean $(\mu)$, standard deviation $(\sigma)$ and Cronbach alpha $(\alpha)$ values of the variables.

\begin{tabular}{l|c|ccc|ccc}
\hline \multirow{2}{*}{ Risk Categories } & & \multicolumn{3}{c|}{ Impact } & \multicolumn{3}{c}{ Probability } \\
\cline { 3 - 8 } & Numb & $\begin{array}{c}\text { Mean } \\
(\mu)\end{array}$ & $\begin{array}{c}\text { Standard } \\
\text { Deviation } \\
(\sigma)\end{array}$ & $\begin{array}{c}\text { Cronbach } \\
\text { Alfa }(\alpha)\end{array}$ & $\begin{array}{c}\text { Mean } \\
(\mu)\end{array}$ & $\begin{array}{c}\text { Standard } \\
\text { Deviation } \\
(\sigma)\end{array}$ & $\begin{array}{c}\text { Cronbach } \\
\text { Alfa }(\alpha)\end{array}$ \\
\hline Risks caused by design & 8 & 3.708 & 0.960 & 0.743 & 3.030 & 0.972 & 0.789 \\
$\begin{array}{l}\text { Economic and market } \\
\text { risks }\end{array}$ & 11 & 3.989 & 0.918 & 0.877 & 3.235 & 0.927 & 0.822 \\
$\begin{array}{l}\text { Political and social risks } \\
\text { Construction risks }\end{array}$ & 8 & 3.530 & 0.932 & 0.846 & 2.860 & 1.025 & 0.771 \\
$\begin{array}{l}\text { Site risks } \\
\text { Contractual risks }\end{array}$ & 18 & 3.668 & 0.920 & 0.924 & 2.949 & 0.980 & 0.924 \\
$\begin{array}{l}\text { Occupational safety and } \\
\text { environmental risks }\end{array}$ & 5 & 3.678 & 0.907 & 0.851 & 2.917 & 0.961 & 0.800 \\
\hline
\end{tabular}

The Cronbach Alpha value is a weighted standard mean of change found by proportioning the sum of the variances of the questions in the example to the general variance. A Cronbach alpha value of 0.70 
and above refer that the questions in that category are considered reliable [21]. The reliability analysis results provided in Table 4 show that the sub-risks under the main risk categories are consistent.

In the risk assessment stage, the median values of the impact and probability data of each risk factor were used. The median values of the impact and probability values for all risk factors were calculated by means of the data analysis program. The size of each risk was calculated by multiplying the impact and probability values and their significance levels and orders within their groups are provided in Table 5 .

Tablo 5. Size and importance of risk and order of importance.

\begin{tabular}{|c|c|c|c|c|c|c|}
\hline $\begin{array}{l}\text { Risk } \\
\text { Code }\end{array}$ & $\begin{array}{l}\text { Risk } \\
\text { Categories }\end{array}$ & Impact & Probability & Risk Size & $\begin{array}{c}\text { Importance } \\
\text { Level }\end{array}$ & $\begin{array}{c}\text { Order of } \\
\text { Importance }\end{array}$ \\
\hline RCD1 & & 4 & 3 & 12 & Medium & 1 \\
\hline RCD2 & & 4 & 3 & 12 & Medium & 1 \\
\hline RCD3 & & 4 & 3 & 12 & Medium & 1 \\
\hline RCD4 & Risks caused & 4 & 3 & 12 & Medium & 1 \\
\hline RCD5 & by design & 4 & 3 & 12 & Medium & 1 \\
\hline RCD6 & & 3 & 3 & 9 & Medium & 2 \\
\hline RCD7 & & 4 & 3 & 12 & Medium & 1 \\
\hline RCD8 & & 4 & 3 & 12 & Medium & 1 \\
\hline EMR1 & & 5 & 4 & 20 & High & 1 \\
\hline EMR2 & & 4 & 4 & 16 & High & 2 \\
\hline EMR3 & & 4 & 4 & 16 & High & 2 \\
\hline EMR4 & & 4 & 3 & 12 & Medium & 4 \\
\hline EMR5 & & 4 & 3 & 12 & Medium & 4 \\
\hline EMR6 & Economic and & 4 & 2 & 8 & Medium & 6 \\
\hline EMR7 & & 4 & 3 & 12 & Medium & 4 \\
\hline EMR8 & & 4 & 3 & 12 & Medium & 4 \\
\hline EMR9 & & 4 & 3 & 12 & Medium & 4 \\
\hline EMR10 & & 5 & 3 & 15 & High & 3 \\
\hline EMR11 & & 3 & 3 & 9 & Medium & 5 \\
\hline PSR1 & & 3 & 2 & 6 & Low & 6 \\
\hline PSR2 & & 3 & 3 & 9 & Medium & 4 \\
\hline PSR3 & & 3 & 3 & 9 & Medium & 4 \\
\hline PSR4 & Political and & 4 & 3 & 12 & Medium & 2 \\
\hline PSR5 & social risks & 5 & 2 & 10 & Medium & 3 \\
\hline PSR6 & & 4 & 4 & 16 & High & 1 \\
\hline PSR7 & & 4 & 2 & 8 & Medium & 5 \\
\hline PSR8 & & 3 & 3 & 9 & Medium & 4 \\
\hline CR1 & & 4 & 3 & 12 & Medium & 2 \\
\hline CR2 & & 4 & 3 & 12 & Medium & 2 \\
\hline CR3 & & 4 & 4 & 16 & High & 1 \\
\hline CR4 & & 4 & 3 & 12 & Medium & 2 \\
\hline CR5 & & 3 & 3 & 9 & Medium & 3 \\
\hline CR6 & Construction & 4 & 2 & 8 & Medium & 4 \\
\hline CR7 & risks & 3 & 3 & 9 & Medium & 3 \\
\hline CR8 & & 3 & 3 & 9 & Medium & 3 \\
\hline CR9 & & 4 & 3 & 12 & Medium & 2 \\
\hline CR10 & & 4 & 2 & 8 & Medium & 4 \\
\hline CR11 & & 4 & 3 & 12 & Medium & 2 \\
\hline CR12 & & 3 & 3 & 9 & Medium & 3 \\
\hline
\end{tabular}


Tablo 5(continue). Size and importance of risk and order of importance.

\begin{tabular}{|c|c|c|c|c|c|c|}
\hline $\begin{array}{l}\text { Risk } \\
\text { Code }\end{array}$ & $\begin{array}{l}\text { Risk } \\
\text { Categories }\end{array}$ & Impact & Probability & Risk Size & $\begin{array}{c}\text { Importance } \\
\text { Level }\end{array}$ & $\begin{array}{c}\text { Order of } \\
\text { Importance }\end{array}$ \\
\hline CR13 & \multirow{6}{*}{$\begin{array}{l}\text { Construction } \\
\text { risks }\end{array}$} & 4 & 3 & 12 & Medium & 2 \\
\hline CR14 & & 4 & 3 & 12 & Medium & 2 \\
\hline CR15 & & 4 & 4 & 16 & High & 1 \\
\hline CR16 & & 4 & 2 & 8 & Medium & 4 \\
\hline CR17 & & 4 & 3 & 12 & Medium & 2 \\
\hline CR18 & & 3 & 3 & 9 & Medium & 3 \\
\hline SR1 & \multirow{12}{*}{ Site risks } & 4 & 2,5 & 10 & Medium & 3 \\
\hline SR2 & & 4 & 3 & 12 & Medium & 2 \\
\hline SR3 & & 4 & 3 & 12 & Medium & 2 \\
\hline SR4 & & 3 & 3 & 12 & Medium & 2 \\
\hline SR5 & & 4 & 3 & 12 & Medium & 2 \\
\hline SR6 & & 3 & 4 & 12 & Medium & 2 \\
\hline SR7 & & 3 & 3 & 9 & Medium & 4 \\
\hline SR8 & & 4 & 4 & 16 & High & 1 \\
\hline SR9 & & 3 & 3 & 9 & Medium & 4 \\
\hline SR10 & & 5 & 2 & 10 & Medium & 3 \\
\hline SR11 & & 4 & 3 & 12 & Medium & 2 \\
\hline SR12 & & 4 & 2 & 8 & Medium & 5 \\
\hline COR1 & \multirow{5}{*}{$\begin{array}{l}\text { Contractual } \\
\text { risks }\end{array}$} & 3 & 3 & 9 & Medium & 2 \\
\hline COR2 & & 4 & 3 & 12 & Medium & 1 \\
\hline COR3 & & 4 & 3 & 12 & Medium & 1 \\
\hline COR4 & & 4 & 3 & 12 & Medium & 1 \\
\hline COR5 & & 4 & 3 & 12 & Medium & 1 \\
\hline OSER1 & \multirow{7}{*}{$\begin{array}{l}\text { Occupational } \\
\text { safety and } \\
\text { environmental } \\
\text { risks }\end{array}$} & 4 & 4 & 16 & High & 1 \\
\hline OSER2 & & 4 & 4 & 16 & High & 1 \\
\hline OSER3 & & 4 & 3 & 12 & Medium & 2 \\
\hline OSER4 & & 3 & 4 & 12 & Medium & 2 \\
\hline OSER5 & & 4 & 3 & 12 & Medium & 2 \\
\hline OSER6 & & 3,5 & 3 & 10,5 & Medium & 3 \\
\hline OSER7 & & 3 & 3 & 9 & Medium & 4 \\
\hline
\end{tabular}

Risk significance level is demonstrated in three stages in risk analysis performed by decision matrix method: (1) low (risk size $\leq 6$ ), (2) medium $(6<$ risk size $<15)$, (3) high (risk size $\geq 15$ ). In Table 5, the significance levels of 69 risk factors used in the analysis were obtained as follows: 10 high risk, 58 medium risk and 1 low risk. The order of importance of the sub-risks constituting the risk categories indicates the order of the steps to be taken to remove or reduce the risks.

\section{CONCLUSION}

Highway projects are large investment projects and have many risk factors. In this study, 69 risk factors have been classified under 7 main groups based on the literature of these risk factors. These risk factors have been evaluated by 50 technical staff who have been working. The assessment procedure has been carried out by paying due attention, thus, any data loss has not occurred. As it applies to any scientific study, this study has certain limitations related to time, financial resources, human capacity to think and interpret. Investigating the risk assessment in highway projects, this research is an empirical study, and its conclusions are limited to the subjects of this study.

When examining the results provided in Table 5, it is seen that EMR1 (economic crisis) risk under economic and market risks has the highest risk value. This main risk factor has the highest average risk 
among other risk groups. PSR6 under the heading of political/social risks, CR3 and CR15 under the heading of construction risks, SR8 under the heading of site risks, and OSER1 and OSER2 under the heading of occupational safety and environmental risks are distinguished as other important risk factors.

The most important contribution of this study to the related literature is the fact that possible risks that will affect the project at the initial stage of a highway project can be rapidly evaluated and resolved by using the results obtained in this investigation. Accordingly, highway projects can be fulfilled by considering estimated time-cost-quality and likely conflicts and losses will be removed. It is suggested to carry out further studies with more risk factors by increasing the number of subjects for data collection.

\section{REFERENCES}

[1] M. Çebin, "Otoyol projelerinde gecikme nedenlerinin ve sonuçlarının araştırılması," Yüksek lisans tezi, İnşaat Mühendisliği Bölümü, Balıkesir Üniversitesi, Balıkesir, Türkiye, 2019.

[2] M.M. Sharaf and H.T. Abdelwahab, "Analysis of risk factors for highway construction projects in Egypt," Journal of Civil Engineering and Architecture, vol. 9, no. 5, pp. 526-533, 2015.

[3] T. Birgönül and İ. Dikmen, "İnşaat projelerinin risk yönetimi," İnşaat Mühendisleri Odası Teknik Dergi, c. 7, s. 4, ss. 1305-1326, 1996.

[4] N. Vasishta, D.S. Chandra, and S.S. Asadi, "Analysis of risk assesment in construction of highway projects using relative importance index method," International Journal of Mechanical Engineering and Technology, vol. 9, no. 3, pp. 1-6, 2018.

[5] Project Management Institute (PMI), A Guide to the project management body of knowledge, 2017.

[6] M.A. Mustafa and J.F. Al-Bahar, "Project risk assessment using the analytic hierarchy process," IEEE Transactions on Engineering Management, vol. 38, no. 1, pp. 46-51, 1991.

[7] J. H. M. Tah, A. Thorpe and R. McCaffer, "Contractor project risks contingency allocation using linguistic approximation,” Computing System in Engineering, vol. 4, no. 2, pp. 281-293, 1993.

[8] F. Özbey, "Ulaşım altyapı projelerinde risk değerlendirmesi ve alternatif uyuşmazlık çözüm uygulamaları,” Yüksek lisans tezi, İnşaat Mühendisliği Bölümü, İstanbul Teknik Üniversitesi, İstanbul, Türkiye, 2015.

[9] A. Vishwakarma, and A. Salunkhe, "Risk assesment in construction of highway project," International Journal of Engineering Research \& Technology, vol. 5, no. 2, pp. 637-640, 2016.

[10] P. X. W. Zou, G. Zhang and J. Wang, "Identifying key risks in construction projects: Life cycle and stakeholder perspectives," Journal of Civil Engineering and Architecture, vol. 18, pp. 1-14, 2006.

[11] V.W.Y Tam, L.Y. Shen, C.M. Tam and W.W.S. Pang, "Investigating the intentional quality risks in public foundation projects: A Hong Kong study," The International Journal of Building Science and Its Application, vol. 42, no. 1, pp. 330-343, 2007.

[12] I. Mahamid, A. Bruland and N. Dmaidi, "Delay causes in road construction projects," ASCE Journal of Management in Engineering, vol. 28, no. 3, pp. 300-310, 2012. 
[13] P. Thapanont, C. Santi, X. Pruethipong, "Causes of delay on highway construction projects in Thailand," The 4th International Conference on Engineering, Applied Sciences and Technology (ICEAST 2018), 2018, pp. 1-4.

[14] L. Edwards, Practical Risk Management in The Construction Industry, London: Thomas Telford Publications, 1995, pp. 60-90.

[15] J. Perera, I. Dhanasinghe, and R. Rameezdeen, "Risk management in road construction: The case of Sri Lanka," International Journal of Strategic Property Management, vol. 13, pp. 87-102, 2009.

[16] J.J. Reilly and J. Brown, "Management and control of cost and risk for tunneling and infrastructure projects," Proceedings, World Tunneling Conference, International Tunneling Association, 2004.

[17] M.R. Aydos, "Üst yapı inşaatlarında ön tehlike analizi (PHA) ile risk değerlendirmesi," İşs sağlığı ve güvenliği uzmanlık tezi, Çalışma ve Sosyal Güvenlik Bakanlığı, Ankara, Türkiye, 2015.

[18] B. B. Xu, Y. Q. Chen and C.M. Wang, "Risk management of construction projects based on sandpile model: A frame of risk conduction," IEEE International Conference on Industrial Engineering and Engineering Management, 2013, pp. 1530-1534.

[19] T.C. Kinnear and J.R. Taylor, Marketing Research: An Applied Approach, McGraw-Hill, Singapore, 1991, pp. 150-230.

[20] M. Çaylıdemirci, "Nehir tipi hidroelektrik santral yatırımı inşaatlarında karşılaşılan risklerin belirlenmesi,” Yüksek lisan tezi, İnşaat Mühendisliği Ana Bilim Dalı, İstanbul Teknik Üniversitesi, İstanbul, Türkiye, 2010.

[21] K. Sandal, "İnşaat firmalarında alt yüklenici başarım analizi," Yüksek lisans tezi, İnşaat Mühendisliği Bölümü, Balıkesir Üniversitesi, Balıkesir, Türkiye, 2019. 